\title{
Pollination and breeding system of Couepia uiti (Mart. and Zucc.) Benth (Chrysobalanaceae) in the Pantanal da Nhecolândia
}

\author{
Paulino-Neto, HF* \\ Programa de Pós-graduação em Ecologia, Instituto de Biologia, \\ Universidade Estadual de Campinas - UNICAMP, \\ CP 6109, CEP 13083-970, Campinas, SP, Brazil \\ *e-mail: hipolitopaulino@yahoo.com.br
}

Received August 24, 2005 - Accepted May 29, 2006 - Distributed November 30, 2007

(With 3 figures)

\begin{abstract}
The pollination biology and breeding system of Couepia uiti was studied. In this species, flowers opened at 06:00 AM anthesis, and nectar production began at around $0800 \mathrm{~h}$, reached a maximum volume from 09:30 AM to 10:30 AM, and decreased thereafter. The nectar sugar concentration increased continuously, but showed an abrupt increase from 10:00 AM to 12:00 AM. Pollen release occurred at about 09:30 AM and was quickly collected. The stigmas became receptive at around 12:00 AM. The pollinators of C. uiti included the bees Apis mellifera, Xylocopa sp. and Bombus sp., and three species of wasps. This conclusion was based on the observation that these hymenopterans had $C$. uiti pollen on their bodies, visited the receptive flowers, and touched the anthers and stigmas, thereby promoting pollination. Of these floral visitors, A. mellifera was considered to be the most efficient pollinator. However, mixed pollination also occurred. The number of $C$. uiti flowers visited in the morning $(\mathrm{n}=52)$ was three times smaller than in the afternoon $(n=62)$, and the species richness of floral visitors was also bigger in the afternoon (eight in the afternoon versus five in the morning). This finding indicated that these floral visitors preferred to exploit nectar rather than pollen. Controlled pollination experiments showed that $C$. uiti was a self-incompatible species that produced fruits only by cross-pollination. Treatments such as agamospermy and spontaneous and self-pollinations did not produce fruits.
\end{abstract}

Keywords: breeding system, chrysobalanaceae, Couepia uiti, hymenoptera, pollination biology.

\section{Polinização e sistema reprodutivo de Couepia uiti (Chrysobalanaceae, no Pantanal da Nhecolândia}

\begin{abstract}
Resumo
Estudei a biologia da polinização e o sistema reprodutivo de Couepia uiti. Esta espécie apresentou antese matutina, produção de néctar iniciou por volta das 08:00 horas, atingindo volume máximo entre 09:30 e 10:30 horas e diminuindo após este horário. A concentração de açúcares no néctar aumentou continuamente, apresentando aumento abrupto entre 10:00 e 12:00 horas. A liberação de pólen ocorreu às 09:30 horas e este foi rapidamente removido. O estigma estava receptivo às 12:00 horas. Considerei polinizadores de C. uiti as abelhas: Apis mellifera, Xylocopa sp., Bombus sp. e três espécies de vespas, pois apresentaram polén de $C$. uiti em seus corpos. Visitaram flores quando estavam receptivas, tocando as anteras e os estigmas, promovendo a polinização. Dentre os visitantes florais, A. mellifera foi considerado o polinizador mais eficiente, no entanto, polinização mista parece ocorrer. O número de visitas a flores de $C$. uiti pela manhã $(\mathrm{n}=52)$ foi três vezes menor que o encontrado no período da tarde $(\mathrm{n}=162)$ e o número de espécies de visitantes também foi maior à tarde, sendo encontradas cinco espécies durante a manhã e oito à tarde. Portanto, é possível concluir que estes visitantes florais preferem explorar o néctar em comparação ao pólen. Os tratamentos de polinizações controladas mostraram que $C$. uiti é uma espécie auto-incompatível, produzindo frutos somente por polinização cruzada. Tratamentos de agamospermia, polinização espontânea e autopolinização não produziram frutos.
\end{abstract}

Palavras-chave: sistema reprodutivo, chrysobalanaceae, Couepia uiti, hymenoptera, biologia da polinização.

\section{Introduction}

With the exception of the breeding systems of Couepia polyandra (Kunth) Rose (1899) (Bullock, 1985), and Hirtella glandulosa Spreng and Hirtella gracilipes (Hook f.) (1967) Prance (Arista et al., 1997), the reproductive biology of the Chrysobalanaceae spe-

cies has been poorly studied. In studies indicated above, C. polyandra (Benth.) Prance (1969) and H. glandulosa (Spreng, 1753) were considered to be self-incompatible, whereas $H$. gracilipes was self-compatible. The pollination biology of this group also remains little stud- 
ied, with only records of bat pollination in Maranthes polyandra (Benth.) Prance (Lack, 1978) and pollination by butterflies in $H$. glandulosa and $H$. gracilipes (Arista et al., 1997). In this study, the pollination biology and breeding system of $C$. uiti in the southern Pantanal, in southwestern Brazil was investigated.

\section{Materials and Methods}

\subsection{Plant species studied}

Couepia uiti (Mart. Et. Zucc.) is an arboreous species 3.0-6.0 $\mathrm{m}$ in height, with a wide crown reaching $4 \mathrm{~m}$ in diameter. In the study area, this species grows in native pastures in sandy grassland with fluvial inundation and riparian forest. Flowering occurs from August to November (Pott and Pott, 1994).

\subsection{Study site}

This work was done along the margins of the Rio Negro on the Fazenda Rio Negro, in Pantanal da Nhecolândia, Mato Grosso do Sul (19 $34^{\circ}$ S and $\left.56^{\circ} 14^{\prime} \mathrm{W}\right)$, from October $6^{\text {th }}$ to November $24^{\text {th }}, 2001$, with the field observations and breeding system studies being concentrated from the $6^{\text {th }}$ to the $10^{\text {th }}$ of October. The remaining time was used for supplementary observations on fruit development and fruit set census. Data were gathered at three sites located $1-2 \mathrm{~km}$ apart, at the co-ordinates $19^{\circ} 34^{\prime} \mathrm{S}$ and $56^{\circ} 15^{\prime} \mathrm{W}$ (site 1), $19^{\circ} 35^{\prime} \mathrm{S}$ and $56^{\circ} 14^{\prime} \mathrm{W}$ (site 2 ) and $19^{\circ} 35^{\prime} \mathrm{S}$ and $56^{\circ} 14^{\prime} \mathrm{W}$ (site 3 ). The co-ordinates and the distances among the three sites were obtained using a GPS.

\subsection{Floral biology}

To determine the floral biology, including nectar volume and concentration, five trees some $50 \mathrm{~m}$ apart at site 3 were observed to monitor the floral visitors. The breeding system was studied using 15 trees (five at each site). The floral visitors were also monitored by hourly censuses of three trees at each site. Different flowers were used to study the floral biology, to record the nectar and for the controlled pollination experiments.

Ten flowers were marked and observed daily on each of five trees to determine the flower longevity, timing and sequence of the following anthesis events: anther dehiscence, stigma receptivity and corolla changes over five consecutive days. Nectar was collected over four days from 10 flowers of five individuals at hourly intervals from 06:00 AM to 04:00 PM using $10 \mu \mathrm{L}$ microcapillaries. The nectar volume was determined just during the period of activity of floral visitors that was until 04:00 PM. After 04:00 PM no floral visitors were observed. The nectar volume was determined by measuring the column length in the capillary, and the nectar sugar concentration of 10 flowers from five individuals was recorded pre-anthesis phase to avoid visits by potential pollinators. Stigmatic receptivity was assessed using $\mathrm{H}_{2} \mathrm{O}_{2}$ (Dafni, 1992).

\subsection{Breeding system}

The breeding system was assessed by manual selfand cross-pollinations. The pollen was collected in the morning and used in controlled pollinations early in the afternoon, when the flowers were receptive. Untreated and emasculated buds were bagged to verify spontaneous pollination and agamospermy, respectively. The agamospermy treatment used here did not cover pseudogamy. For the cross-pollinations, pollen from trees belonging to three sites was used to ensure that the individuals were the least related as possible. Control flowers were tagged without treatment to assess the success of natural pollinations. The results of the breeding system were used to calculate the index of self-incompatibility (ISI), which is the ratio between the fruit set resulting from self- versus cross-pollination (Bullock, 1985).

\subsection{Floral visitors}

Floral visitors were censored using 10 minutes observations in three plants, to give a total of 30 minutes per hour of observation. These observations were made from 07:00 AM-16:00 PM on three days, with one day for each site (a total of 27 hours of censoring). Specimens of all of the floral visitors observed were captured for identification.

\section{Results}

\subsection{Pollination breeding system}

Anthesis began early in the morning (06:00 AM). The flowers starting anthesis showed a loosening of the petals to form an orifice in which it was possible to see plicate and spiralled stamens with pale yellow anthers. At this stage, there was no nectar production, pollen was still not available and the stigmas were not receptive. By the end of anthesis, the stamens gradually expanded and acquired an erect position, the anthers became dark yellow, and the petals expanded and were held erect. Nectar was produced by the pilose and annular nectary in the hypanthium, where it accumulated as small droplets for the floral visitors. The nectar was apparently not reabsorbed since its volume increased continuously from early in the morning until 04:00 PM. The nectar volume gradually increased up to 09:30 AM and reached a maximum between 09:30 AM and 10:00 AM. The volume then decreased continuously until about 14:00 PM and gradually increased again (Figure 1a). In general, the sugar concentration increased continuously, although there was an abrupt increase in the nectar sugar concentration between 11:00 AM and 12:00 AM (Figure 1b). Anthers dehisced at 09:30 AM, and pollen was quickly removed by the floral visitors. By 12:00 AM, few flowers still had pollen available. The stigmas were receptive from 12:00 AM to the end of the afternoon. The functional flowers lasted one day, but dropped off only on the third day while the stamens persisted for approximately four days. And after 4 or 5 days, immature fruits beginning their development were observed. 

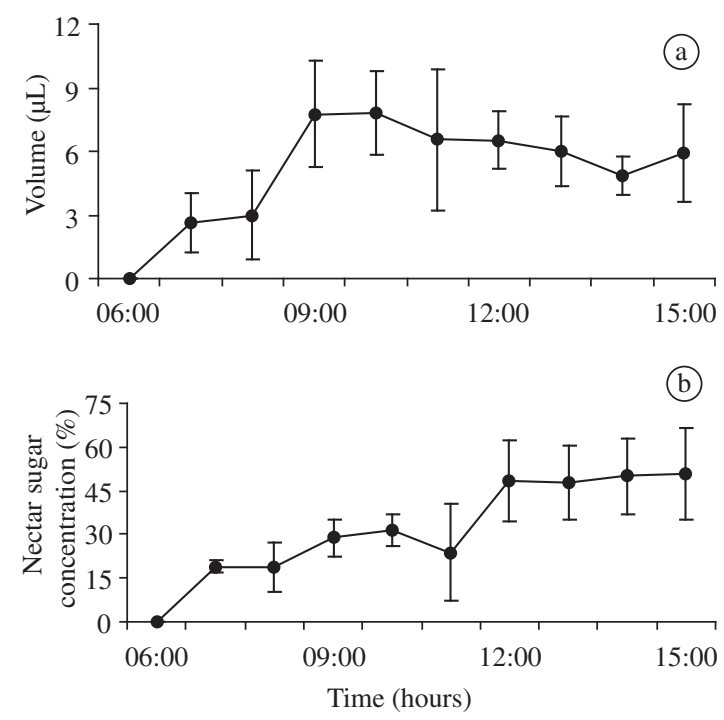

Figure 1. a) Nectar volume; and b) nectar sugar concentration of the Couepia uiti, Fazenda Rio Negro, Pantanal da Nhecolândia, Mato Grosso do Sul.

According to Bullock (1985), plants with an index of self-incompatibility (ISI: the ratio of fruit set from selfpollinated versus cross-pollinated flowers) smaller than 0.25 are considered self-incompatible. Based on this criterion, the breeding system experiments showed that C. uiti was self-incompatible, with fruits produced exclusively by cross-pollination (Table 1). Agamospermy treatment and spontaneous and self-pollinations did not produce fruits.

\subsection{Floral visitors}

The first floral visitors began to inspect the $C$. uiti flowers from the beginning of anthesis (06:00 AM). Apis mellifera (Linnaeus, 1758) visited flowers and touched the reproductive structures, thereby promoting pollination. This species was the most frequently observed $(61 \%, \mathrm{n}=232$ floral visits) and visited more flowers than all of the other visitors together. In addition, two wasp species (Vespidae) also showed a high visiting rate $(31 \%, \mathrm{n}=116)$. Visits by other species were rare $(<$ $2 \% ; \mathrm{n}=6$ ) (Figure 2). The latter visitors included bees (Xylocopa sp., Centris sp., Trigona spinipes (Fabricius, 1793)), one species of wasp (Scoliidae) and an unidentified ashen colored butterfly species. At other sites along the margins of the Rio Negro, other floral visitors were observed, including the bees Bombus sp., Frisiomelitta varia (Friese, 1900), and Oxytrigona tataira (Smith, 1863), a mosquito species, one species of Syrphidae and another indeterminate fly species, in addition to the birds Paroaria captata (Orbigny and Lafresnaye, 1837) (Emberezidae), Eupetomena macroura (Gmelin, 1788) and Hylocharis chrysura (Shaw, 1812) (Trochilidae). Of all of the visitors, A. mellifera, Xylocopa sp., Bombus sp. and both wasp species represented legitimate visits. Paroaria captata only pillaged nectar, without promot-
Table 1. Fruit set from controlled pollinations of flowers of Couepia uiti (Chrysobalanaceae), Fazenda Rio Negro, Pantanal da Nhecolândia, Mato Grosso do Sul.

\begin{tabular}{lccc}
\hline \multicolumn{1}{c}{ Treatments } & $\begin{array}{c}\text { Flowers } \\
(\mathbf{n})\end{array}$ & $\begin{array}{c}\text { Fruits } \\
(\mathbf{n})\end{array}$ & $\begin{array}{c}\text { Success } \\
(\boldsymbol{\%})\end{array}$ \\
\hline $\begin{array}{l}\text { Cross pollination } \\
\text { (Xenogamy) }\end{array}$ & 40 & 6 & 11.11 \\
Agamospermy & 20 & 0 & 0 \\
Self-pollination & 25 & 0 & 0 \\
Spontaneous pollination & 30 & 0 & 0 \\
Natural conditions & 45 & 5 & 15.0 \\
(Control) & & & \\
\hline
\end{tabular}

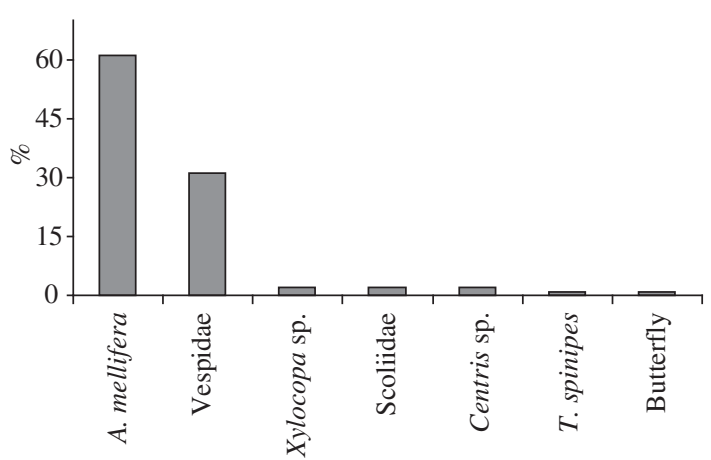

Figure 2. Frequency of visitor species in flowers of Couepia uiti, Fazenda Rio Negro, Pantanal da Nhecolândia, Mato Grosso do Sul.

ing pollination since visits by this species did not involve touching the reproductive structures. The hummingbirds E. macroura and $H$. chrysura were recorded only at site 1 , where they showed a high frequency of visits to flowers of different $C$. uiti plants. These hummingbirds apparently promoted pollination because they also appeared to undertake legitimate visits in which they touched the anthers and stigmas, and frequently flew among various individuals of $C$. uiti, thereby favouring cross-pollination.

The number of flowers visited from 07:00 AM to 11:00 AM was three times smaller than the number visited from 12:00 AM to 04:00 PM, i.e., 52 and 162, respectively (Figure 3 ). The species richness of visitors was also higher in the afternoon (Figure 3).

\section{Discussion}

The floral morphology of $C$. uiti fitted the syndrome of melitophily (Proctor et al., 1996). Flowers of C. uiti offered nectar and pollen to the visitors and were pollinated mainly by bees. Couepia uiti flowers received more visits from an increased number of visiting species only when nectar was more concentrated. A similar pattern has also been observed in plant species pollinated by bees (e.g. Waller, 1972; Bachman and Waller, 1977; Pyke and Waser, 1981; Proctor et. al., 1996). 


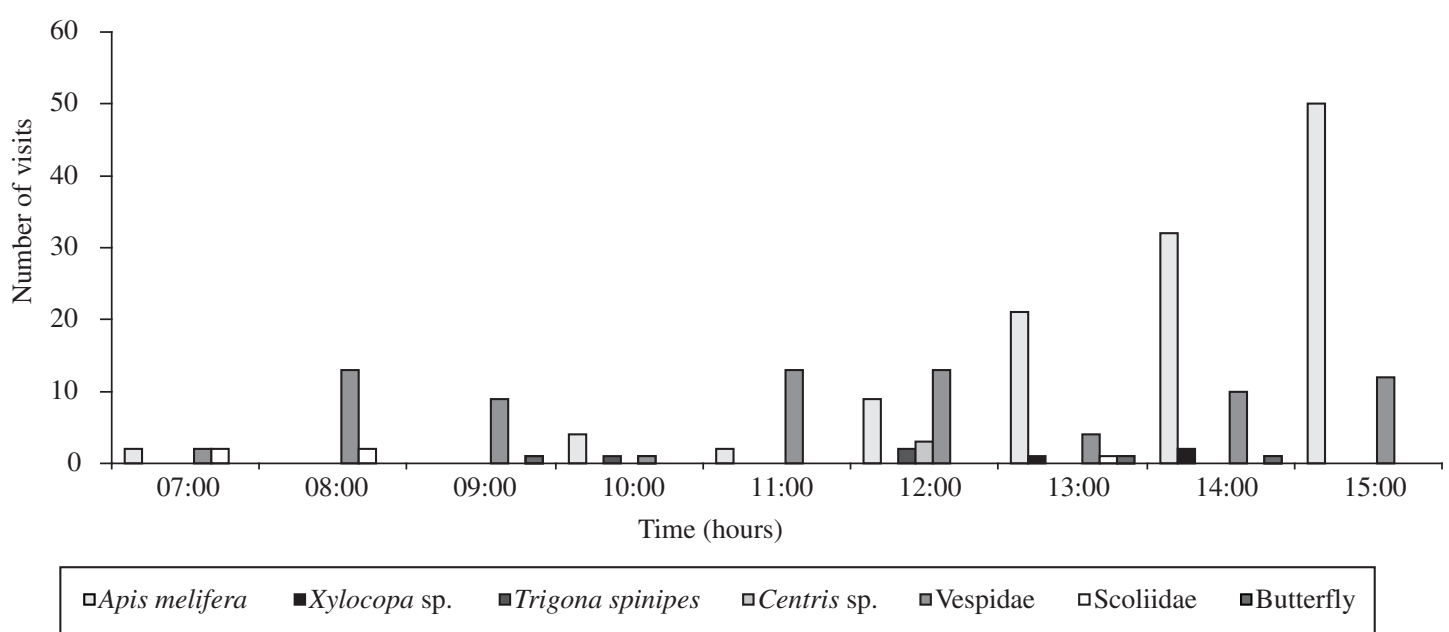

Figure 3. Number of visits and flower visitors of Couepia uiti, Fazenda Rio Negro, Pantanal da Nhecolândia, Mato Grosso do Sul.

The nectar sugar concentration can show considerable variation because of evaporation and changes in humidity (Proctor et. al., 1996). Hence, the decline in the nectar volume after 10:00 AM may be related to an increase in temperature and high evaporation rates. Temperature can affect the nectar volume and sugar concentration because nectar accumulates in the external part of the nectar chamber and is subject to wind and solar radiation. The continuous production of nectar combined with continuous water evaporation may account for the progressive increase in the nectar sugar concentration of C. uiti flowers.

The results of fruit set from self- versus cross-pollinations indicated that $C$. uiti was a self-incompatible species with an ISI of zero (Bullock, 1985). Although $H$. gracilipes was reported to be a self-compatible species (Arista et al., 1997), self-incompatibility appears to be the tendency in Chrysobalanaceae since self-incompatibility occurs in C. polyandra (Bullock, 1985), H. glandulosa (Arista et al.,1997) and also in C. uiti. However, since there have been few studies of the breeding system in this plant family, more studies are necessary to confirm this tendency.

The fruit set of manual cross-pollinations seen here was less than for natural pollinations, which is unusual in this type of experiment. The heterogeneity of the pollen used in these experiments was restricted to flowers of five plants at each site, whereas this pollen heterogeneity is generally much higher in natural pollinations. In this specific case, in addition to A. mellifera which can carry the pollen of numerous flowers of different plants for greater distances, the action of secondary pollinators can still increase the pollen heterogeneity. Since $C$. uiti is a self-incompatible species and the pollen used in these experiments was much less heterogeneous than that of natural pollinations, the fruit set resulting from manual pollinations was smaller. The pollinators were probably more efficient and deposited more pollen on the stigmas than was deposited in manual pollinations.

Agamospermy and spontaneous pollination tests did not produce fruits, indicating that this species is highly dependent on external pollinators. Other Chrysobalanaceae species, such as $H$. glandulosa and $H$. gracilipes, also produced no fruit by agamospermy or spontaneous pollination (Arista et al., 1997).

Most floral visitors of $C$. uiti were bees. The main pollinator species of C. uiti were A. mellifera, Xylocopa sp., Bombus sp., and wasp species. All of these visitors had C. uiti grains adhered to their bodies, visited receptive flowers and touched the anthers and stigmas, thereby promoting pollination. Apis mellifera was the most frequent pollinator and visited more flowers than all of the other visitors combined. The number of flowers visited is very important for the reproductive success of plants (Waser, 1983). However, in the case of C. uiti, the behaviour of the floral visitors and the morphology of the flowers indicated that bumblebees (Xylocopa and Bombus spp.) were the main pollinators because their mode of touching the anthers and the stigmas was more efficient. In addition, bumblebees can perform a higher number of cross-pollinations since they can fly longer distances. The finding that $A$. mellifera, a non-native bee introduced into the Americas, is a more assiduous pollinator of $C$. uiti than are native species is quite remarkable since the opposite was expected. The hummingbirds E. macroura and $H$. chysura were also potential pollinators. Consequently, the low fruit set recorded (15\%) for natural pollination may reflect competition between A. mellifera and bumblebees, with a consequent reduction in the number of visits by efficient, native pollinators. Further studies are required to assess the efficiency of pollen deposition on stigmas and the resulting fruit set in order to determine whether bumblebees really are the main pollinators. 
The fact that $C$. uiti flowers were visited by animals of different groups (bees, wasps, butterflies, and birds) may be a consequence of the large floral display that consists of inflorescences with flowers in different developmental stages. The presence of inflorescences with open flowers may increase the visitation rate, as observed for H. glandulosa (Arista et al., 1997). In addition, the accumulation of nectar at a depth of 2-4 $\mathrm{mm}$ in an annular nectary in the hypanthium makes this store accessible to a large range of insects and small birds. A similar pattern has also been reported by Arista et al. (1997) for Hirtella spp. In the latter study, although long-tongued flies, bees and hummingbirds were observed in the study areas, they never visited $H$. glandulos $a$ and $H$. gracilipes flowers, which were pollinated exclusively by butterflies. The high sugar concentration of the nectar observed here may explain the absence of butterflies from $C$. uiti flowers since these vectors prefer only moderately concentrated nectar (Arista et al., 1997; Faegri and van der Pijl, 1979).

Acknowledgments - I thank Erich Fischer, Coordinator of the Curso de Mestrado em Ecologia e Conservação da Universidade Federal do Mato Grosso do Sul, and all of his team for organizing the field course "Ecologia de Campo do Pantanal" during which this study was done, and also for valuable comments on the manuscript. I also thank Conservation International do Brasil for supporting this important course in ecology. Erich Fischer and Milton Longo provided helpful suggestions and discussions on the methodology used and also provided some of the equipment necessary for this work. I am very grateful to two anonymous reviewers for helpful suggestions and criticisms on the manuscript. Isabel Alves dos Santos of the Universidade do Extremo Sul Catarinense (UNESC) and Favízia Oliveira of the Universidade Federal do Paraná (UFPR) kindly identified the specimens collected. Celso Silva, Neli Silva, Geni Fialho, Elisângela Serra, Márcia Muskope and Miguelita Duarte helped with the fieldwork, and Leonardo França, Reinaldo Teixeira and Priscilla Amaral also helped in various ways. I thank Rodrigo and Tasso for their hospitality at Fazenda Rio Negro. This work was supported by CAPES (grant no. 724/00). Sincere thanks also to Maria Sueli Duarte Paulino and Cristiane Maria de Lima, who were helpful during all phases of this study.

\section{References}

ARISTA, M., OLIVEIRA, PE., GIBBS, P. and TALAVERA, S., 1997. Pollination and breeding system of two co-occurring Hirtella species (Chrysobalanaceae) in central Brazil. Bot. Acta, vol. 110 , no. 6, p. 496-502.

BULLOCK, SH., 1985. Breeding systems in the flora of a tropical deciduous forest in Mexico. Biotropica, vol. 17, no. 4, p. 287-301.

BACHMAN, WW. and WALLER, GD., 1977. Honeybee responses to sugar solutions of different compositions. J. Apicult. Research, vol.16, p. 165-173.

DAFNI, A., 1992. Pollination Ecology: a Practical Approach. Oxford: IRL Oxford University Press.

FAEGRI, K. and VAN der PIJL, L., 1979. The Principles of Pollination Ecology. London: Pergamon Press.

LACK, A., 1978. The ecology of the flowers of the savanna tree Maranthes polyandra and their visitors, with particular reference to bats. J. Ecol., vol. 66, no.1, p. 287-295.

POTT, A. and POTT, VJ., 1994. Plantas do Pantanal. Empresa Brasileira de Pesquisa Agropecuária, Centro de Pesquisa Agropecuária do Pantanal. EMBRAPA-SPI, Corumbá, 320p.

PROCTOR, M., YEO, P. and LACK, A., 1996. The Natural History of Pollination. Oregon: Harper Collins Publishers.

PYKE, GH. and WASER, NM., 1981. The production of dilute nectars by hummingbird and honeyeater flowers. Biotropica, vol. 13 , p. $260-270$

WALLER, GD., 1972. Evaluating responses of honeybees to sugar solutions using an artificial-flower feeder. Ann. Entomol. Soc. Am., vol. 65, p. 857-862.

WASER, NM., 1983. The adaptative nature of floral traits: ideas and evidence. In REAL, LA. (ed.). Pollination Biology. Florida: Academic Press, p. 241-285. 